\title{
Defining the Geotourism Potential of the CILENTO, Vallo di Diano and Alburni UNESCO Global Geopark (Southern Italy)
}

\author{
Ettore Valente ${ }^{1}\left(\mathbb{D}\right.$, Annarita Casaburi $^{2}$, Michele Finizio ${ }^{2}$, Lorenzo Papaleo ${ }^{2}$, Alessia Sorrentino ${ }^{2}(\mathbb{D}$ \\ and Nicoletta Santangelo ${ }^{1, *(D)}$ \\ 1 Department of Earth, Environment and Resources Sciences (DiSTAR), University of Naples Federico II, \\ Via Cinthia 21, 80126 Naples, Italy; ettore.valente@unina.it \\ 2 ASNU aps-Associazione Scienze Naturali Unite, via Mezzocannone 8, 80134 Naples, Italy; \\ annar.casaburi@gmail.com (A.C.); mich.finizio@gmail.com (M.F.); lorenzopapaleo95@gmail.com (L.P.); \\ alessia.sorrentino195@gmail.com (A.S.) \\ * Correspondence: nicsanta@unina.it
}

check for updates

Citation: Valente, E.; Casaburi, A.; Finizio, M.; Papaleo, L.; Sorrentino, A.; Santangelo, N. Defining the Geotourism Potential of the CILENTO, Vallo di Diano and Alburni UNESCO Global Geopark (Southern Italy). Geosciences 2021, 11, 466. https://doi.org/10.3390/ geosciences 11110466

Academic Editors:

Teresa Brzezińska-Wójcik,

Maria Górska-Zabielska and

Jesus Martinez-Frias

Received: 11 October 2021

Accepted: 8 November 2021

Published: 10 November 2021

Publisher's Note: MDPI stays neutral with regard to jurisdictional claims in published maps and institutional affiliations.

Copyright: (c) 2021 by the authors. Licensee MDPI, Basel, Switzerland. This article is an open access article distributed under the terms and conditions of the Creative Commons Attribution (CC BY) license (https:/ / creativecommons.org/licenses/by/ $4.0 /)$.

\begin{abstract}
The interest of the scientific community about geotourism is abruptly increasing, as well as that on geoparks. According to UNESCO, geoparks should define management policies addressed to increasing the awareness of local people and tourists about Earth's dynamics to reduce the impact of climate change and natural disasters. With this aim in mind, we tried to provide a solid scientific approach to geotourism that could be useful to the development of a geotourism strategy in the Cilento, Vallo di Diano and Alburni (CVDA) Geopark, in Southern Italy. Starting from the official inventory of the CVDA Geopark, we defined the potential Education Value (EV) and potential Touristic Value (TV) of each of the 160 sites listed by applying the Brilha method. Then we selected 20 geosites and geomorphosites with high values of both the EV and TV, and we included them in two geoitineraries. The two geoitineraries move in the inner sector of the Geopark (i.e., from the Paestum archaeological area to the Vallo di Diano basin) and along a portion of the coastal stretch (i.e., from Punta Telegrafo cape to the Lambro and Mingardo rivers' mouths). Selected sites are representative of several geoscience disciplines (e.g., geomorphology, structural geology, quaternary geology, hydrogeology), thus suggesting that the CVDA Geopark is an ideal place where dissemination of geoscience concepts may be carried out. The latter point enhances the high geotourism potential of the area. This kind of approach was not tried before in the CVDA Geopark and can be a useful example of how to promote touristic development strategies in the area.
\end{abstract}

Keywords: geosites; geomorphosites; educational use; touristic use; geoitinerary

\section{Introduction}

Geotourism is a growing approach to classical natural tourism that aims to combine the dissemination of the geological-paleontological heritage of a territory with a sustainable increase in the local economy ([1] and reference therein). The increasing interest in geotourism is clearly expressed by the large number of international papers dealing with this topic [2-7]. Geotourism can be approached from both a geographical and a geological point of view ([8] and reference therein), and both approaches have been combined in the Arouca declaration [9]. It is worthy to note that, in this paper, we adopted the geological approach to geotourism. Sites of geological interest that are prone to be included in a geotourism program are the geosites and geomorphosites. The former refers to portions of the geosphere useful for reconstructing the history of the Earth, climate, and life [10], whereas the latter refers to portions of the landscape of, among all, high scientific, cultural, and aesthetic value [11].

Parallel to the development of geotourism is the establishment of geoparks in many countries of the world. The concept of geopark has been diffused since 1996 [12] and was also supported and endorsed by the Division of Earth Science at United Nations 
Educational, Scientific and Cultural Organization (UNESCO), which proposed a program named the "UNESCO's Geoparks Programme" [12,13]. The definition of geopark suggests a strong connection between geological-paleontological heritage fruition and the development of the local economy [13]. This definition implies that geoparks are the areas where geotourism may be diffused. Furthermore, UNESCO also provided a wider definition of geoparks, which include management policies addressed to increasing the awareness of local people and tourists about Earth's dynamics to reduce the impact of climate change and natural disasters. Geoparks that have adopted this type of policy have been included in the UNESCO Global Geoparks Network (GGN) [14].

GGN includes 169 geoparks mainly spread throughout Europe, Asia, and South America [15]. China and Spain are the countries with the largest number of geoparks included in this network (41 and 15 geoparks, respectively), whereas Italy is in third place, with 11 geoparks that have gained the title of UNESCO Global Geopark. Among Italian geoparks, the Cilento, Vallo di Diano and Alburni (CVDA) Geopark is one of the largest, with an area of $1841 \mathrm{~km}^{2}$. The CVDA Geopark has gained several endorsements since its foundation in 1991 as a National Park. Moreover, it was included in the Man and Biosphere List by UNESCO in 1997 and in the World Heritage List by UNESCO in 1998. It then gained the title of geopark in 2010 and the title of UNESCO Global Geopark in 2015.

The CVDA Geopark exhibits a large variety of geological, geomorphological, and paleontological sites of high scientific interest. A first census of geosites and geomorphosites was carried out by Santangelo et al. [16], who recognized 263 sites that had the potential to be classified as either geosite or geomorphosite. The official catalogue of the CVDA geosites actually includes 160 geosites and geomorphosites [17]. Even though the CVDA Geopark has a high number of sites with relevant scientific interest, just few international papers [18-20], conference proceedings [21,22] and national papers [23-25] discussed the importance of these sites as tools to promote geotourism. Moreover, international papers are focused on specific geoscience topics, such as karst $[18,19]$ and coastal landforms $[19,20]$, but a comprehensive analysis of the geotourism potential of all the 160 geosites and geomorphosites of the CVDA Geopark has never been addressed. Furthermore, we also want to prove that many sites within the CVDA Geopark had the potential to be included in a geotourism program, even if they have not been included in already published geoitineraries [18-20,25]. To tackle this issue, we have tried to define the geotourism potential of all the 160 sites and we have proposed two geoitineraries, one moving in the inner portion of the Geopark and another one moving along a sector of the coastal area. The two geoitineraries include both sites already selected in published geoitineraries and sites never considered of having the potential to be included in a geotourism program. They also enhance the high educational and touristic potential of a large sector of the Geopark, thus suggesting that most of the CVDA Geopark may act as a tourist attractor with positive feedback for the local economy.

\section{Geological Setting of the Cilento, Vallo di Diano and Alburni Geopark}

The CVDA Geopark is placed along the Tyrrhenian flank of the southern Apennines. It is limited by the Sele plain towards the north, by the Vallo di Diano intramontane basin towards the north-east, by the Gulf of Policastro towards the south, and by the Tyrrhenian Sea towards the west (Figure 1). The Southern Apennines are a NE-verging fold and thrust belt formed in Neogene to Quaternary times because of the collision between the Eurasia and African plates [26,27]. Marine Mesozoic carbonate units are diffuse in the entire belt. They correspond with the highest topographic peaks of the chain, with elevation values that approach $2000 \mathrm{~m}$ a.s.l. (Figure 1). Neogene to Miocene wedge-top basin deposits cover the carbonate units, whereas clayey to silty internal unit deposits are preserved in some topographic lows along the Tyrrhenian flank of the chain [28-30]. 


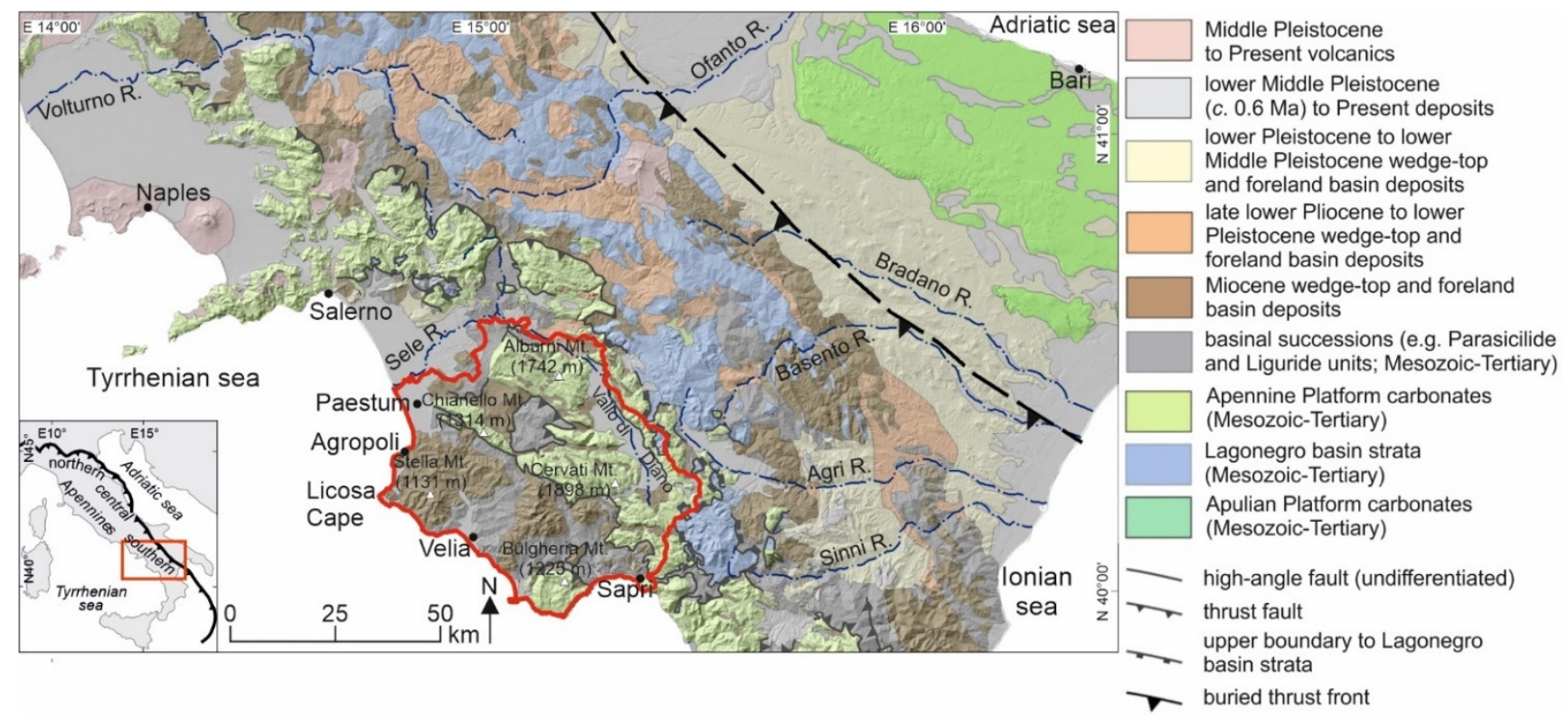

Figure 1. Geological map of the Southern Apennines (modified from [18]). Red line indicates the boundary of the CVDA Geopark.

The above-mentioned deposits are also diffuse in the CVDA Geopark and contribute to its geodiversity [31,32]. Carbonate rocks outcrop to the east of the Geopark and represent its highest peaks (e.g., Alburni Mts., Cervati Mt., Chianello Mt., Figure 1). Carbonate slopes, which are often bounded by steep fault scarps, exhibit both summit karst landscapes and cave systems that host relevant water resources $[18,19,33]$. Miocene wedge-top deposits outcrop in the central and western portion of the CVDA Geopark, where hilly landforms dominate. These deposits are made up of alternating puddingstones, sandstones and mudstones forming the so-called Cilento Group [34-38]. Internal units made up of mainly clayey and silty deposits are preserved in some topographic lows and along some sectors of the coastal belt, such as at Punta Telegrafo near Ascea (Figure 1), where the strongly deformed Crete Nere Formation outcrop is found [39,40]. Quaternary deposits are also present and include marine and continental deposits, mainly made of conglomerates and sandstones, which accumulated both along the coastal strip and in the inner sectors of the Geopark [41-45]. These deposits are well-exposed near Punta Licosa, in the Sele R., Alento R., Mingardo R., and Bussento R. alluvial plains and in the Vallo di Diano intramontane basin (Figure 1).

The above-mentioned different rock-types have been shaped in Quaternary times by different geomorphic processes (e.g., fluvial, marine, aeolian and karst processes), which sculpted both the surface and the subsurface. As a result, several outcrops and landforms have gained relevant scientific significance, being classified as either geosites or geomorphosites [16,23]. The official geosites inventory of the CVDA Geopark include 160 sites [17], which are mainly geomorphosites (54\% of the total), whereas the remaining $46 \%$ of sites have stratigraphical, paleontological, and geological relevance. These data suggest that several places within the CVDA Geopark have great potential in terms of geotourism, even if the promotion and divulgation of this type of tourism is still at an early stage and is limited to few national and international papers [18-24,46-48].

\section{Methods}

To select geosites and geomorphosites that could be included in the geoitineraries, we have adopted the Brilha [49] method by defining the potential Education Value (EV) and potential Touristic Value (TV) of each of the 160 sites listed in the official inventory of the CVDA Geopark [17] (Supplementary Table S1 and Supplementary Table S2, respectively). It is worth noting that the selection and assessment of these 160 sites as either geosites or geomorphosites was carried out by the Geopark administrators. We have chosen the 
EV and the TV indexes of the Brilha [49] method because they could highlight: (1) sites whose geological features may allow to disseminate geological knowledge to people with different levels of education, with comfortable and safe access conditions (EV); (2) sites whose scenic beauty may be appreciated by a large variety of people, even non-specialists (TV). These two indexes result from the sum of several indicators and their relative weights. Most of these indicators are common between the EV and the TV (e.g., vulnerability (V), accessibility (AC), use limitations (UL), safety (SA), logistics (L), density of population (DE), association with other values (AS), scenery (SC), uniqueness (UN), observation conditions $(\mathrm{OC})$ ). Two more indicators contribute to the definition of the EV, which are the didactic potential (DP) and the geological diversity (GD), whereas the TV is completed by the interpretative potential (IP), economic level (EL), and proximity of recreational areas (RA) indicators.

To derive the EV and TV distribution maps, we have georeferenced all geosites and geomorphosites listed in the official inventory of the CVDA Geopark in GIS software (Arcgis 10.7@, Redlands, California, United States of America). A database has been associated with each site, which included all indicators proposed by the Brilha [49] method and their relative weights. As a result, we obtained the spatial distribution of both the EV and the TV with values ranging from 1.5 to 4 .

The EV and TV indexes have been then classified in equally spaced classes (e.g., $1.5-1.99 ; 2.0-2.49 ; 2.5-2.99 ; 3.0-3.49 ; 3.5-4)$. We have then considered sites with values of both indexes larger than 3 and that could be representative of the main geological and geomorphological features of the CVDA Geopark. We selected 20 geosites and geomorphosites and, according to their spatial distribution, included them in two new geoitineraries: the first one moves throughout the inner sector of the Geopark, whereas the second one moves along a sector of the coastal area.

Finally, a Strength, Weaknesses, Opportunity, Threats (SWOT) analysis was carried out to test the potential of both the geoitineraries. This method is normally used for the assessment of geotourism resources and may help to define both the potential of an area in future projects and to propose initiatives for its efficient and effective use [50-52].

\section{Results}

\subsection{Geosites and Geomorphosites Evaluation}

The EV and TV indexes of all geosites and geomorphosites of the CVDA Geopark are shown in Figures 2 and 3, respectively. Details of the values we assigned to each indicator of the Brilha [49] method are listed in Supplementary Table S1 for the EV and Supplementary Table S2 for the TV.

The spatial distribution of both indexes leads to several considerations:

- $\quad$ Thirty-one sites (19\% of the total) gained an EV larger than three;

- $\quad$ Twenty-one sites (13\% of the total) gained a TV larger than three;

- Sites with the highest scores of both indexes are mainly clustered in three areas: the coastal area between San Marco and Marina di Camerota; the inner sector between Mt. Vesole, to the west, and the Vallo di Diano basin to the east; the south-eastern corner of the Geopark between Mt. Centaurino and the Gulf of Policastro;

- There are portions of the CVDA Geopark that already attract many tourists in the summer period, such as the Castellabate and the Palinuro cape area, which also exhibits high values of both the EV and TV indexes, thus suggesting their potential also as a geotourist attractor;

- $\quad$ Some of the sites with the highest scores of the EV and the TV have already been included in published geoitineraries (e.g., the Paestum travertine, the Capo di Fiume spring, the Vallo di Diano basin and the Punta Telegrafo cape) [18-20,25];

- The spatial distribution of the EV and TV indexes (Figures 2 and 3) suggest that a large portion of the CVDA Geopark had the potential to be included in a geotourism program. 


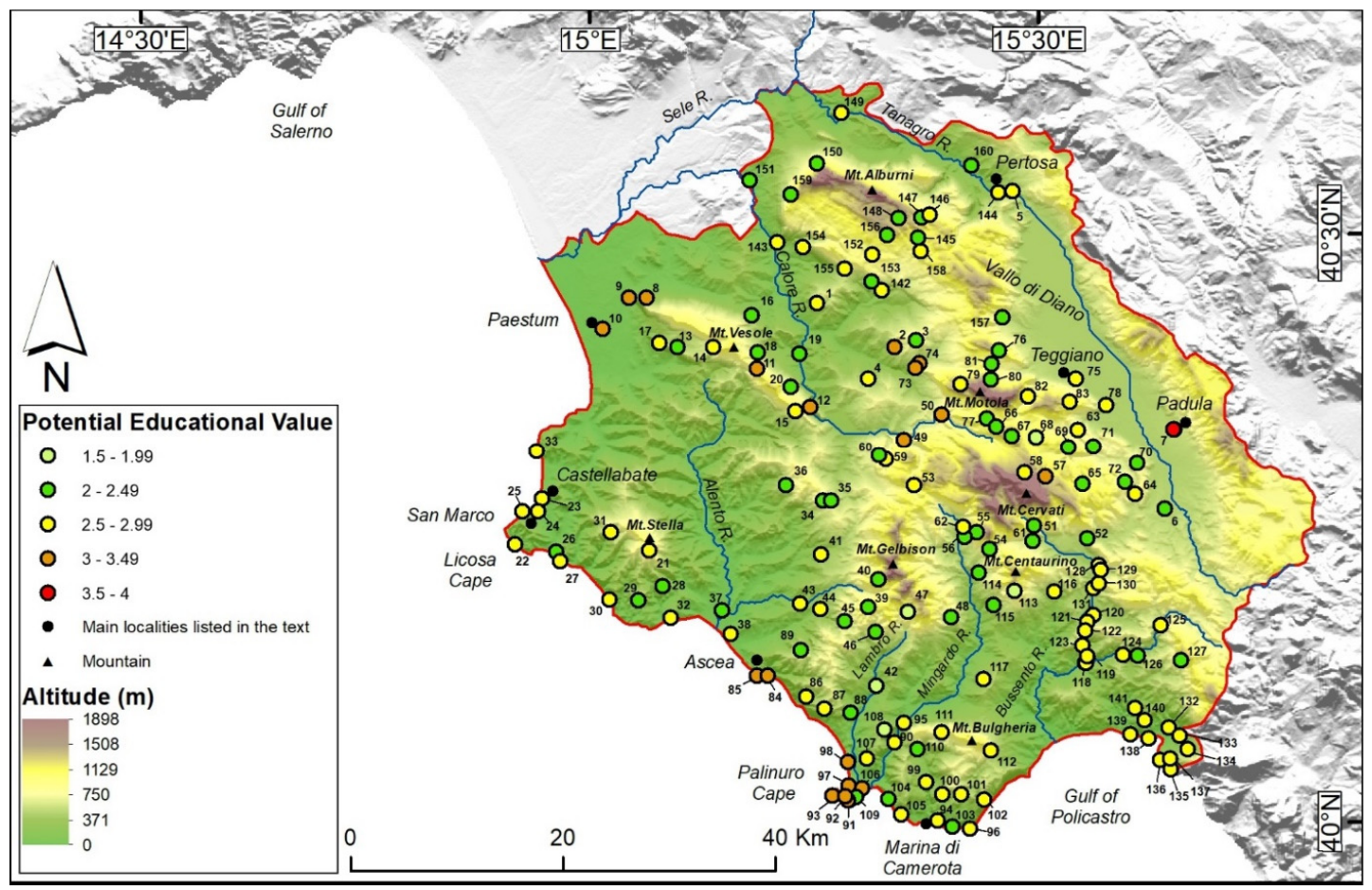

Figure 2. Spatial distribution of the potential Educational Value (EV) of the 160 geosites and geomorphosites listed in the official inventory of the Geopark [17]. Elevation data are derived from the $90 \mathrm{~m}$ SRTM Dtm [53]. Labels refer to Supplementary Table S1.

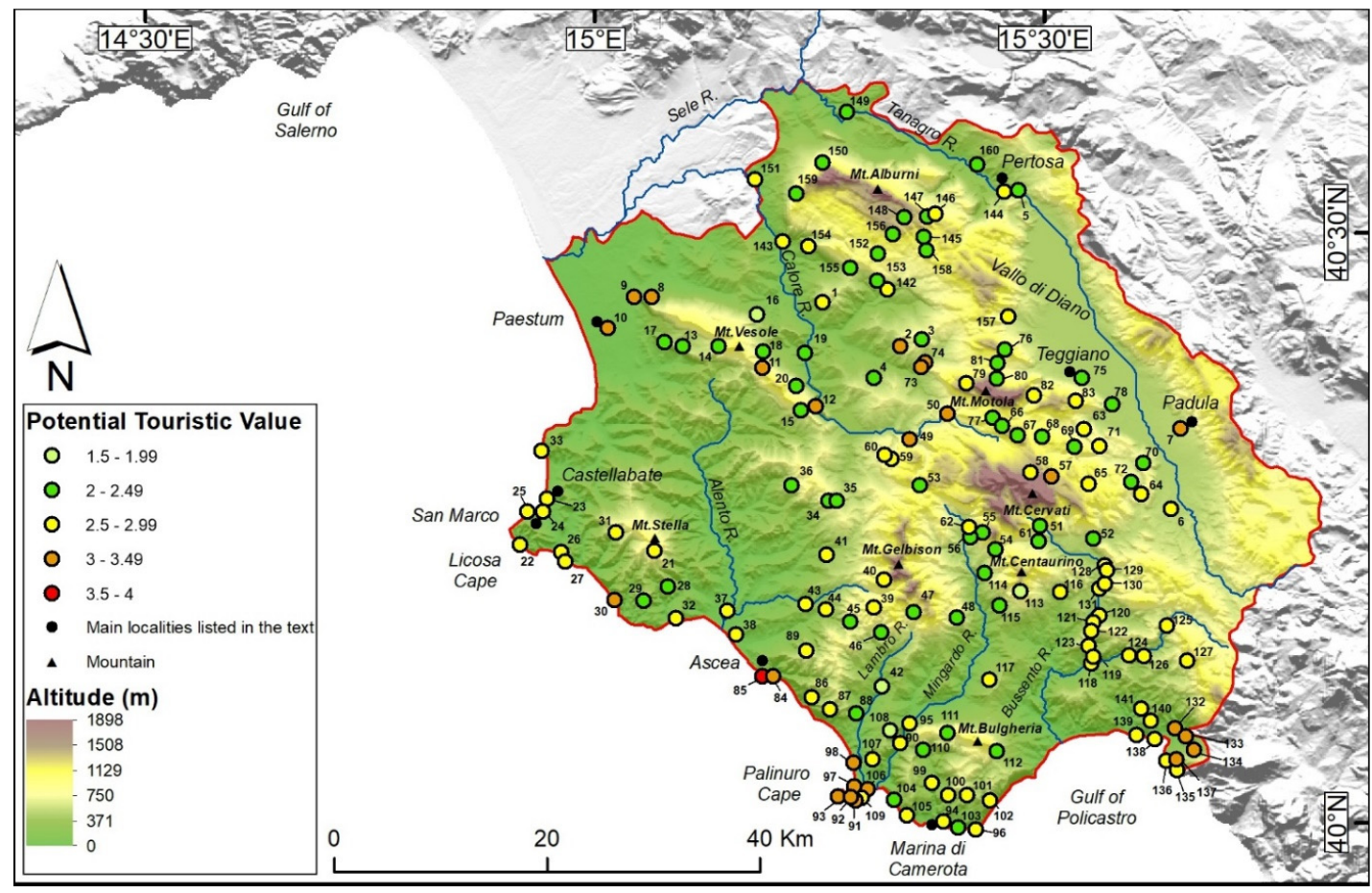

Figure 3. Spatial distribution of the potential Touristic Value (TV) of the 160 geosites and geomorphosites listed in the official inventory of the Geopark [17]. Elevation data are derived from the 90m SRTM Dtm [53]. Labels refer to Supplementary Table S2. 


\subsection{The Geoitineraries}

We selected 20 sites with high values of both the EV and the TV and proposed two geoitineraries (Figure 4), both planned along the main roads of the Geopark, with the aim of showing the high geotourism potential of the area. For this reason, we decided to not provide a technical description (stops, length, indications) of the itineraries, but we centred the description of each stop on the main topics that should be discussed during the visit.

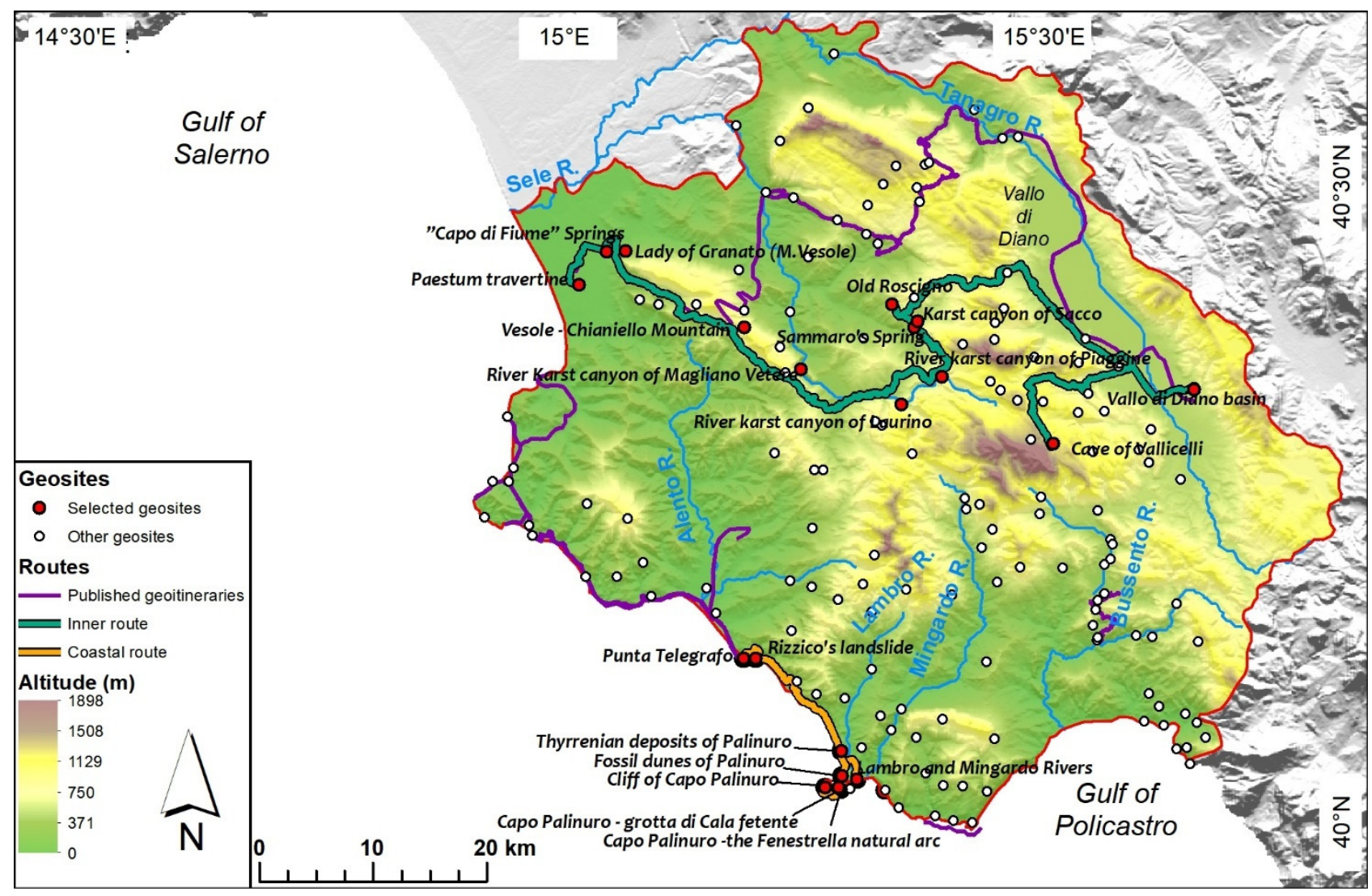

Figure 4. Map showing the two geoitineraries proposed in this paper.

The inner geoitinerary (Figure 4) moves from the archaeological area of Paestum, close to the coastline, towards the Vallo di Diano basin to the east-southeast. It includes (Table 1): morphostructural landforms (the Mt. Vesole and Mt. Chianello cuesta-like slopes and the Vallo di Diano intramontane basin), fluvio-karst landforms (the karst canyons of Magliano Vetere, Laurino, Piaggine and Sacco), a spring (the Sammaro spring), a landslide (near the abandoned town of Roscigno), and a karst area (cave of Vallicelli).

The coastal geoitinerary (Figure 4) moves from Punta Telegrafo cape near the archaeological site of Elea-Velia to the south-east, close to the Palinuro cape area. It includes (Table 1): deformed bedrock units (at Punta Telegrafo), marine landforms (at Punta Telegrafo), a landslide (the Rizzico landslide), marine to continental Quaternary deposits (the Tyrrhenian deposits of Palinuro and the fossil dunes of Palinuro), rocky coasts landforms (the cliff of Capo Palinuro, the coastal caves of Cala Fetente, and the Fenestrella natural arc), and two river mouths (the Lambro and Mingardo rivers).

\subsubsection{The Inner Geoitinerary}

In this sub-section we provide a description of the sites included in the inner geoitinerary, focusing on the main topics that can be discussed for divulgation/teaching purposes.

Paestum Travertine and Capo di Fiume Spring. Main Didactic Topics: Travertine Formation; Stone as Building Materials 
Table 1. Details of the sites included in the proposed geoitineraries.

\begin{tabular}{|c|c|c|c|}
\hline Site Label & Site Name & $\begin{array}{l}\text { Inner Geoitinerary } \\
\text { Field of Interest }\end{array}$ & Description \\
\hline 10 & Paestum travertine & Quaternary geology & $\begin{array}{c}\text { Travertines fed by the Capo di Fiume spring } \\
\text { and accumulated near } \\
\text { the archaeological area of Paestum }\end{array}$ \\
\hline 9 & Capo di Fiume spring & Hydrogeology & $\begin{array}{l}\text { Spring feeding travertine deposition near } \\
\text { the archaeological area of Paestum }\end{array}$ \\
\hline 8 & Lady of Granato (Mt. Vesole) & Paleontology & Limestone with fossil rich layers \\
\hline 11 & Vesole-Chianello Mts. & Geomorphology & Cuesta-like ridge \\
\hline 12 & $\begin{array}{l}\text { Karst canyon of } \\
\text { Magliano Vetere }\end{array}$ & Geomorphology & Fluvio-karst landform \\
\hline 49 & Karst canyon of Laurino & Geomorphology & Fluvio-karst landform \\
\hline 50 & Karst canyon of Piaggine & Geomorphology & Fluvio-karst landform \\
\hline 73 & Sammaro spring & Hydrogeology & Karst spring \\
\hline 74 & Karst canyon of Sacco & Geomorphology & Fluvio-karst landform \\
\hline 2 & Old Roscigno & $\begin{array}{l}\text { Geomorphology } \\
\text { Applied Geology }\end{array}$ & $\begin{array}{l}\text { Active landslide that caused the } \\
\text { abandonment of the old town Roscigno }\end{array}$ \\
\hline 57 & Cave of Vallicelli karst area & $\begin{array}{l}\text { Geomorphology } \\
\text { Geoarchaeology }\end{array}$ & $\begin{array}{c}\text { Karst caves with human frequentation since } \\
\text { Prehistoric time }\end{array}$ \\
\hline 7 & Vallo di Diano basin & $\begin{array}{l}\text { Geomorphology } \\
\text { Quaternary Geology }\end{array}$ & $\begin{array}{l}\text { Largest intramontane basin of the } \\
\text { Southern Apennine }\end{array}$ \\
\hline \multicolumn{4}{|c|}{ Coastal Geoitinerary } \\
\hline Site Label & Site Name & Field of Interest & Description \\
\hline 85 & Punta Telegrafo & $\begin{array}{l}\text { Structural geology } \\
\text { Quaternary geology } \\
\text { Geomorphology }\end{array}$ & Deformed bedrock units and marine terrace \\
\hline 84 & Rizzico landslide & Applied Geology & Landslide potentially affecting the railway \\
\hline 98 & $\begin{array}{l}\text { Tyrrhenian deposits } \\
\text { of Palinuro }\end{array}$ & Quaternary geology & Upper Pleistocene marine deposits \\
\hline 97 & Fossil dunes of Palinuro & Quaternary geology & Upper Pleistocene aeolian deposits \\
\hline 93 & Cliff of Capo Palinuro & Geomorphology & Limestone rocky coast \\
\hline 91 & Fenestrella natural arc & Geomorphology & $\begin{array}{c}\text { Karst landform on the rocky coast of } \\
\text { Palinuro cape }\end{array}$ \\
\hline 92 & Cala Fetente cave & Geomorphology & Cave along the rocky coast of Palinuro cape \\
\hline 106 & $\begin{array}{l}\text { Lambro and Mingardo } \\
\text { rivers mouths }\end{array}$ & Geomorphology & $\begin{array}{l}\text { Palinuro natural arc and entrenched } \\
\text { meanders of the Lambro River }\end{array}$ \\
\hline
\end{tabular}

The archaeological area of Paestum includes amazing remnants of the Greek town of Poseidonia, which was found at the end of the VII cent. BCE and gained the name of Paestum during Roman period [54]. In addition to its historical and archaeological value, the site can also be considered useful to explain the use of travertine rocks as building material. The main buildings and temples of the ancient Greek town are made up of travertines, which are relatively soft rocks largely used up to now as ornamental materials. Travertines are quarried locally because of the presence of three travertine bodies chronologically constrained between the Upper Pleistocene and the Middle Age [54]. Close to the western entrance of the town, named Porta Marina, it is possible to observe nice examples of travertine bodies that completely covered it (Figure 5A).

Travertines originate from the Capo di Fiume spring (Figure 5B), which is the second stop of the geoitinerary. This spring is the point of delivery of the Chianello-Vesole Mts. carbonate aquifer, with a discharge of more than $3 \mathrm{~m}^{3} / \mathrm{s}$ [47]. Water flowing from this spring is intensely mineralized and, once at the surface, precipitation of calcium carbonate occurs, with the consequent formation of travertines. Travertine deposition is still active thus making this site very useful for didactic purposes, allowing the visitors to understand how the calcium carbonate precipitation may preserve vegetal remains.

Lady of Granato and Vesole-Chianello Mts. Main Didactic Topics: Cuesta Like Morphostructural Ridges

The Vesole and Chianello Mts. (Figure 6A,B) are NW-SE trending structural ridges. These ridges are made of a Mesozoic to Miocene succession of carbonate platform limestones and are interpreted as a cuesta. They, in fact, have a steeper flank, to the south-west, and a gentler one, to the north-east, whose dip is equal to the bedding and where flat-irons may be locally recognized. In addition to their morphostructural significance, these mountains also host important paleontological evidence, such as Cretaceous fossilized shrimps and continental plant remains that can be observed at the Magliano Vetere Paleontological Museum [47]. 

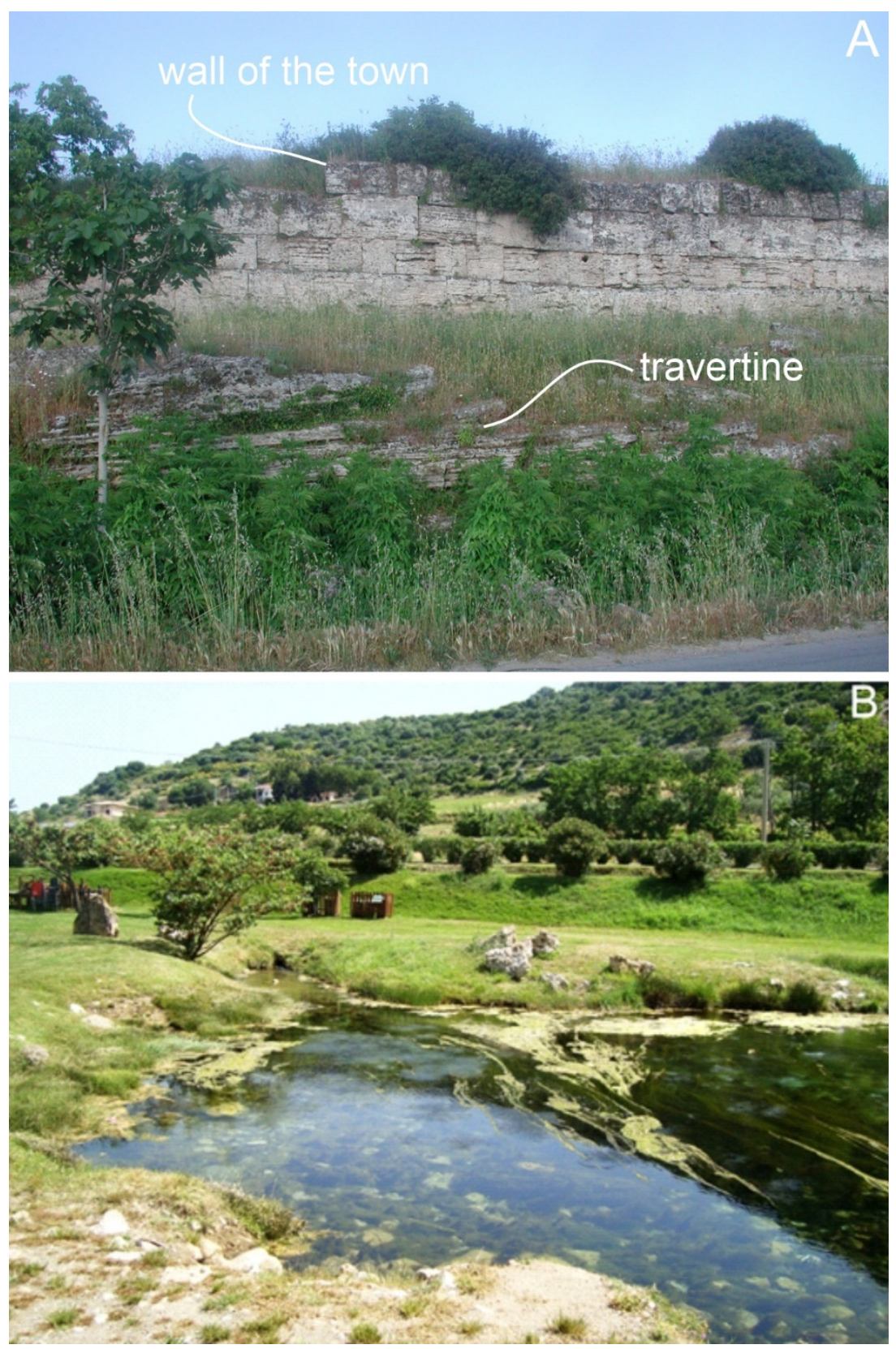

Figure 5. (A) travertine plaque on the wall of the town of Paestum (modified from [55]); (B) the Capo di Fiume Spring.

\section{Karst Canyon of Magliano Vetere, Laurino and Piaggine}

Karst canyons occur in several sectors of the CVDA Geopark and their geotourism potential has been already stated locally, such as for the Middle Bussento Karst System [18] The canyons are 200-500 m deep and are bound by vertical to sub-vertical flanks. The three canyons (Figure 7A-C) intercepted by the inner geoitinerary have been sculpted by the Calore river and are placed in the central sector of the Geopark. In this area, it is common to have lateral contact between "soft" arenaceous-clayey rock-types and "hard" carbonates. This stratigraphical and morphostructural setting makes the Magliano Vetere, Laurino and Piaggine karst canyons nice examples of river superimposition. Along the road there are several panoramic points where it is possible to observe these deep canyons, which make these sites ideal for viewpoint geosites [56], and, in some cases (e.g., the Magliano Vetere canyon), it is possible to practice outdoor activities such as kayaking. 


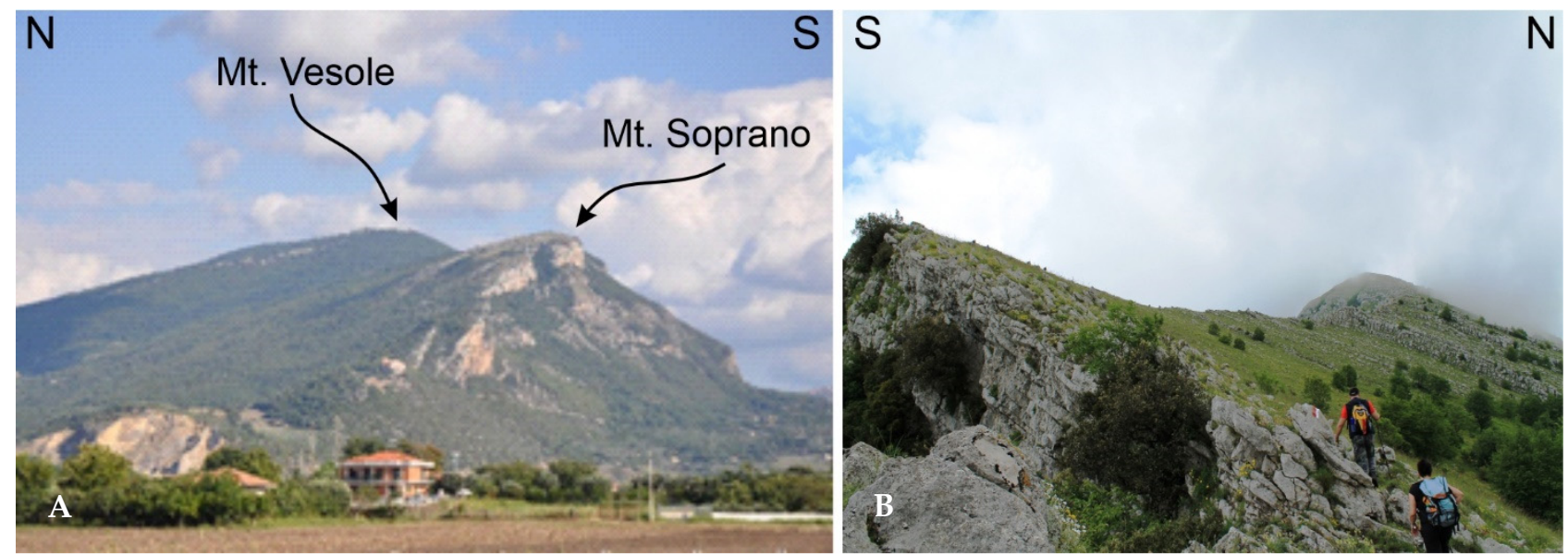

Figure 6. (A) Panoramic view of the Mt. Soprano-Mt. Vesole ridge. The quarry at the base of the northern slope of Mt. Soprano is the Lady of Granato paleontological site; (B) the top of Mt. Chianello, where it is possible to appreciate the coincidence between the dip of calcareous strata and the dip of the slope.

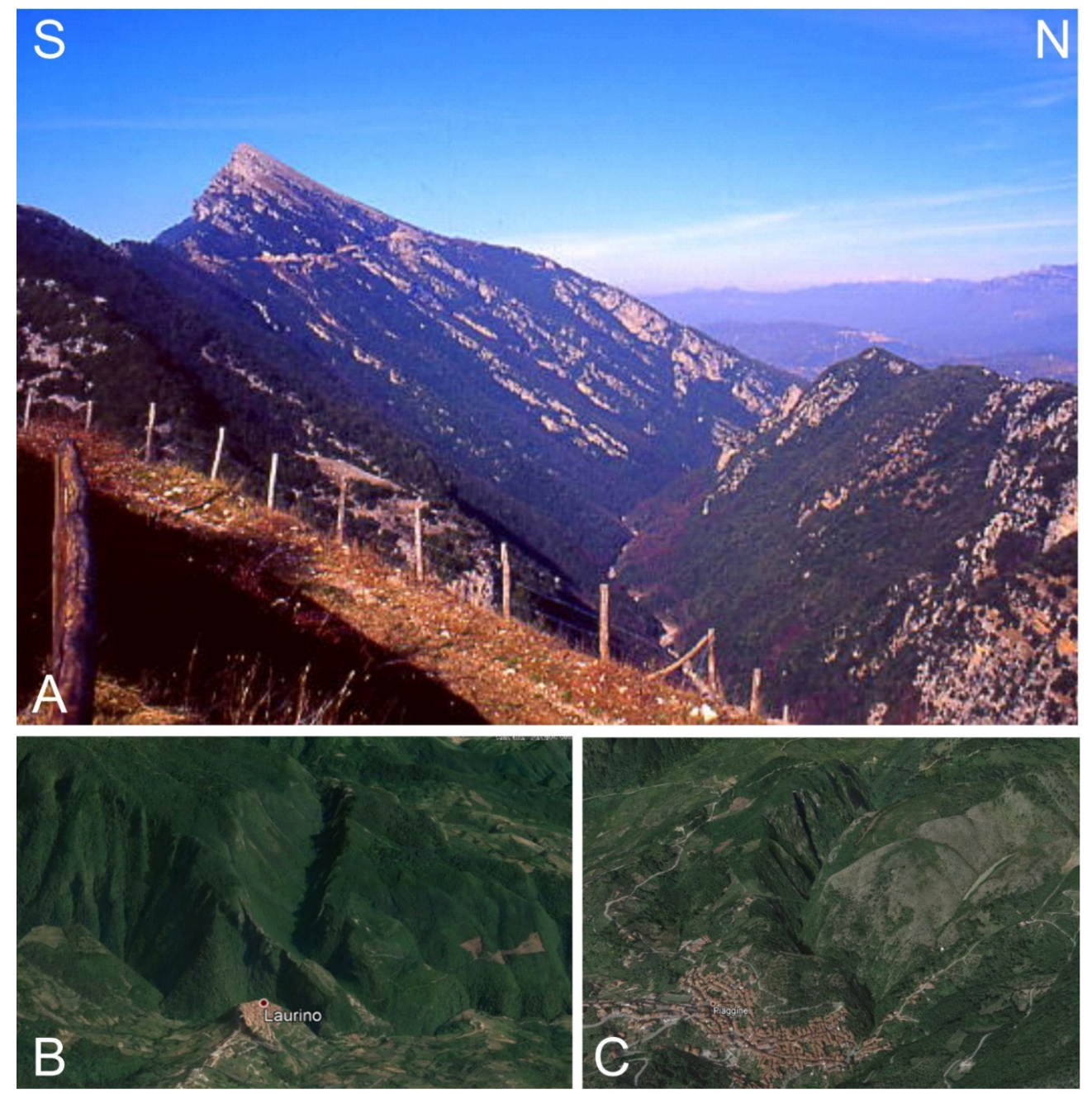

Figure 7. (A) The Magliano Vetere canyon (modified from [47]); (B) Google Earth image of the Laurino canyon; (C) Google Earth image of the Piaggine canyon.

The Sammaro Gorge and the Sammaro Spring. Main Didactic Topics: Karst Canyon, Entrenched Meanders, Karst Spring 
Near the village of Sacco there is the Sammaro river gorge, one of the best examples of karst canyon with entrenched meanders. The canyon is carved by the Sammaro River into the Mesozoic limestone successions of the Motola Mt. The gorge can be observed by panoramic points on its western side or stopping on the bridge of the route SP342 (Figure 8A), thus allowing to interpret it as a viewpoint geosite [56]. At the end of the gorge, it is possible to observe how the presence of the Sammaro karst springs (Figure 8B) increases the mean discharge of the Sammaro streams of several cubic meters.

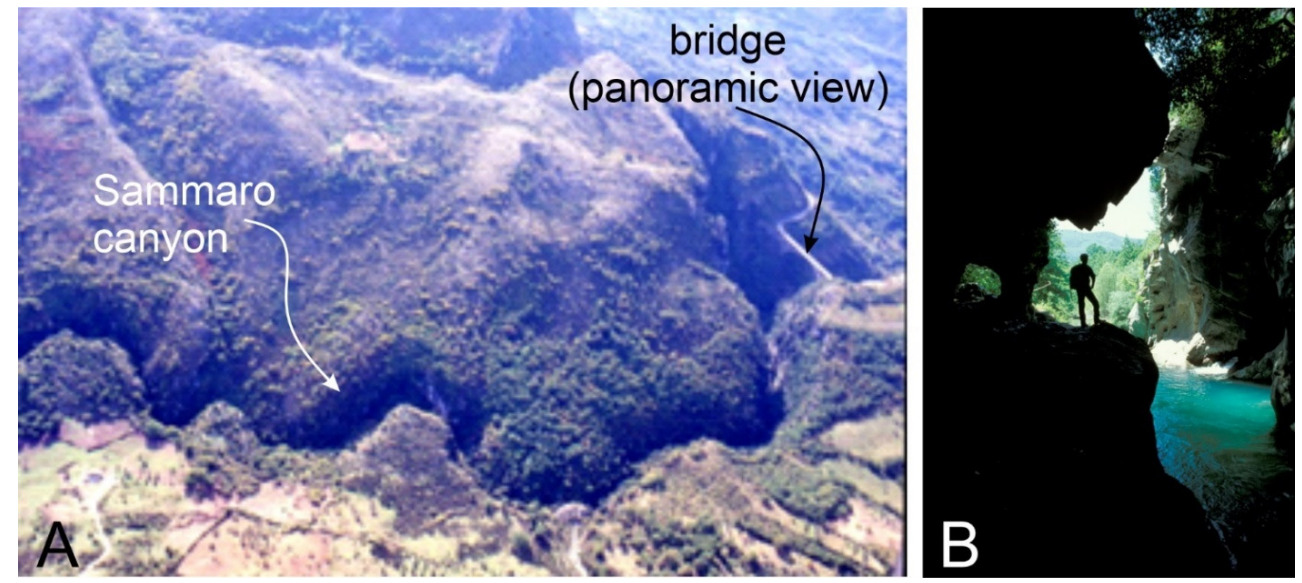

Figure 8. (A) View of the Sammaro River canyon with an indication of the ridge, which serves as a panoramic point of view; (B) the Sammaro spring.

Old Roscigno. Main Didactic Topics: Impact of Landslides on Human Activity

The old village of Roscigno was abandoned in 1964 and the new town has been rebuilt in another location because of the reactivation of an ancient landslide [57] (Figure 9).

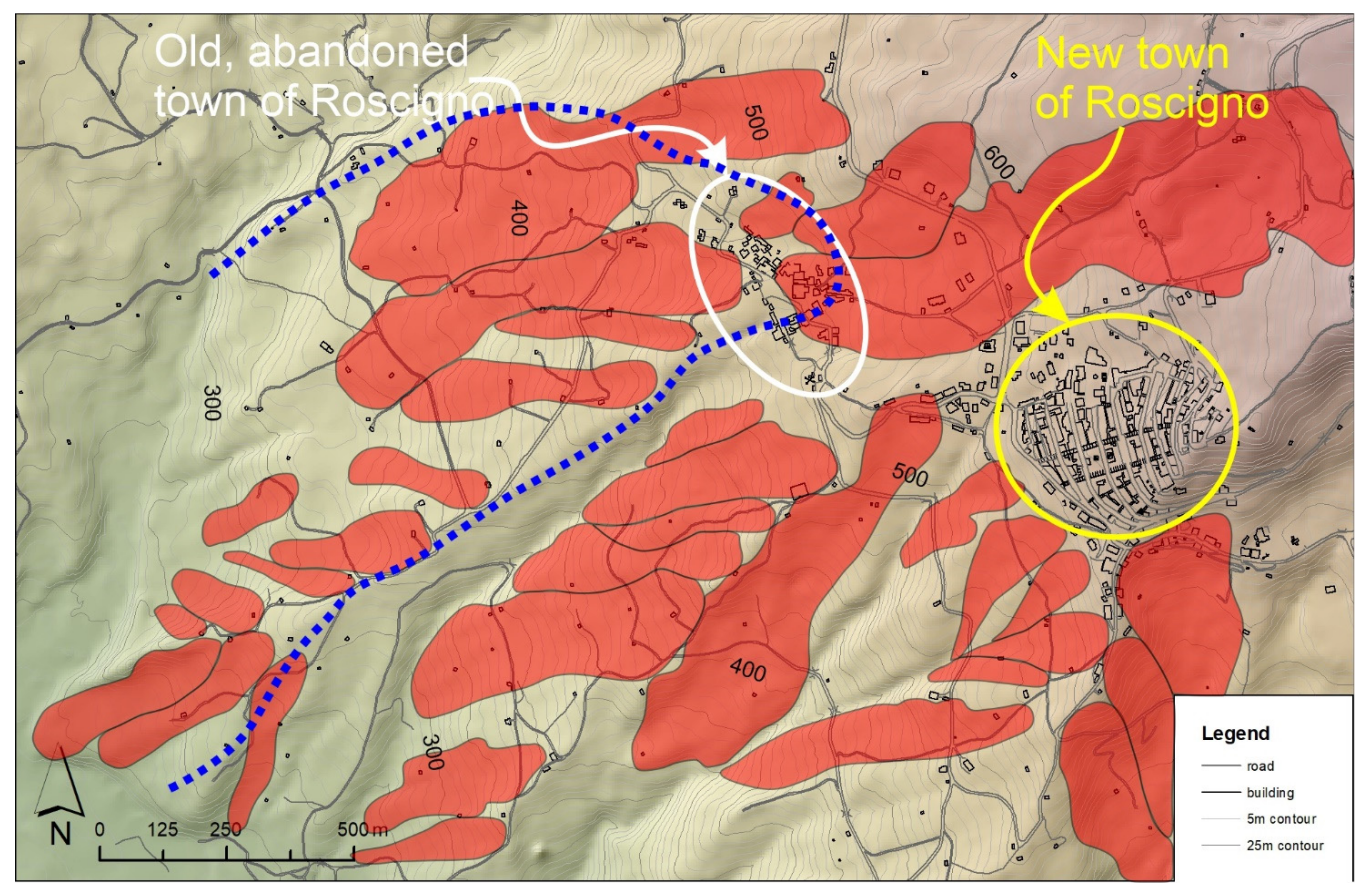

Figure 9. Landslide map of the Roscigno area. The blue dotted line indicates quiescent deep-seated landslide (from De Riso and Santo [58]). Red polygons indicate areas affected by active shallow landslides. The base map is a $5 \mathrm{~m}$ DTM derived by Technical Map of the Campania Region at a scale of 1:5000 [59]. 
The landslide is a huge and complex slide-earth flow affecting a slightly deformed clayey-marly-arenaceous succession [57]. Several authors pointed out the presence of a quiescent deep-seated landslide on top of which several shallow landslides occur (e.g., clay rotational slides, clay rotational slides-earth flows and soil creeps) [57,58]. Furthermore, besides the abandoned town of Roscigno, landsliding also affected the archaeological site of Mt. Pruno and landslide activity could be traced back to the III-IV century BCE [57]. Apart from its value as an example of an ancient rural village of the inner region of the Geopark, it can be useful to explain how, sometimes, the local administrators must make very difficult decisions (village de-localization) to counteract the effect of the landslide risk, which is one of the most widespread geological hazards in the Geopark. The latter point allowed Calcaterra et al. [60] to classify this site as an example of a moving geosite.

Vallicelli Karst Area. Main Didactic Topics: Cave and Human Frequentation

The Vallicelli karst area is characterized by the presence of two little contact ponors (namely the Vallicelli and Varlacarla caves), which are very interesting not only as an example of a karst cave formed at the contact between impermeable terrains (Miocene flysch formation) and carbonates (Mesozoic limestones). They, in fact, preserve a unique prehistorical record from the Middle Bronze age up to the Eneolithic period. In the Varlacarla cave, some evidence suggests that it has been used both for burial purposes and for other ritual practices during the Middle bronze age. The latter is suggested by two large stalagmites (Figure 10) located at the entrance of the main room [61].

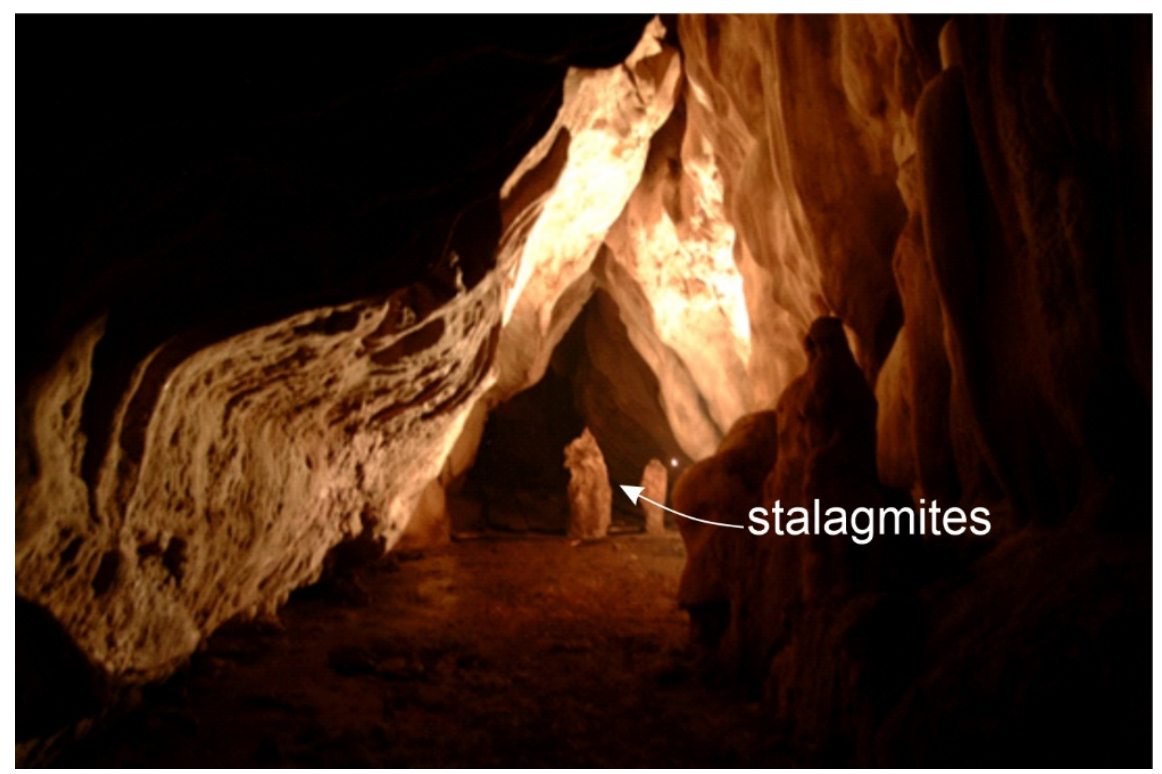

Figure 10. The main room of Varlacarla cave, with the two stalagmites in an unual position, interpreted as a ritual site (modified from [61]).

Vallo di Diano Basin. Main Didactic Topics: Intramontane Basins; Active Fault, Past Climate Changes; Alluvial Fan and Related Hazard

The approximately $30 \mathrm{~km}$ long, 8-10 km wide Vallo di Diano (Figure 11A) is the largest intermontane basin in the southern Apennines. The flat basin floor, which is located at an average elevation of $450 \mathrm{~m}$, corresponds to the slightly dissected top surface of a fluvial-lacustrine and palustrine succession of the Pleistocene-Holocene age (Figure 11B).

The basin is bounded towards the NE by a rectilinear, NW-SE trending, fault-bounded mountain front with an average elevation of $970 \mathrm{~m}$ (the highest peak reaching $1500 \mathrm{~m}$ ). This fault, according to Villani and Pierdominici [62], can be considered as an active and seismogenic fault. The stratigraphical architecture of the Vallo di Diano basin fill has been reconstructed based on outcrop data from both dissected and uplifted deposits and on 
numerous well logs up to $200 \mathrm{~m}$ deep $[63,64]$. The lacustrine succession may be framed in the $700 \mathrm{ky}$ to $250 \mathrm{ky}$ time span [45]. The analysis of the fossil pollen content (i.e., palynology) allowed to reconstruct the climatic history of the region making the lacustrine successions of the Vallo di Diano one of the most valuable record of past climate change in southern Italy.
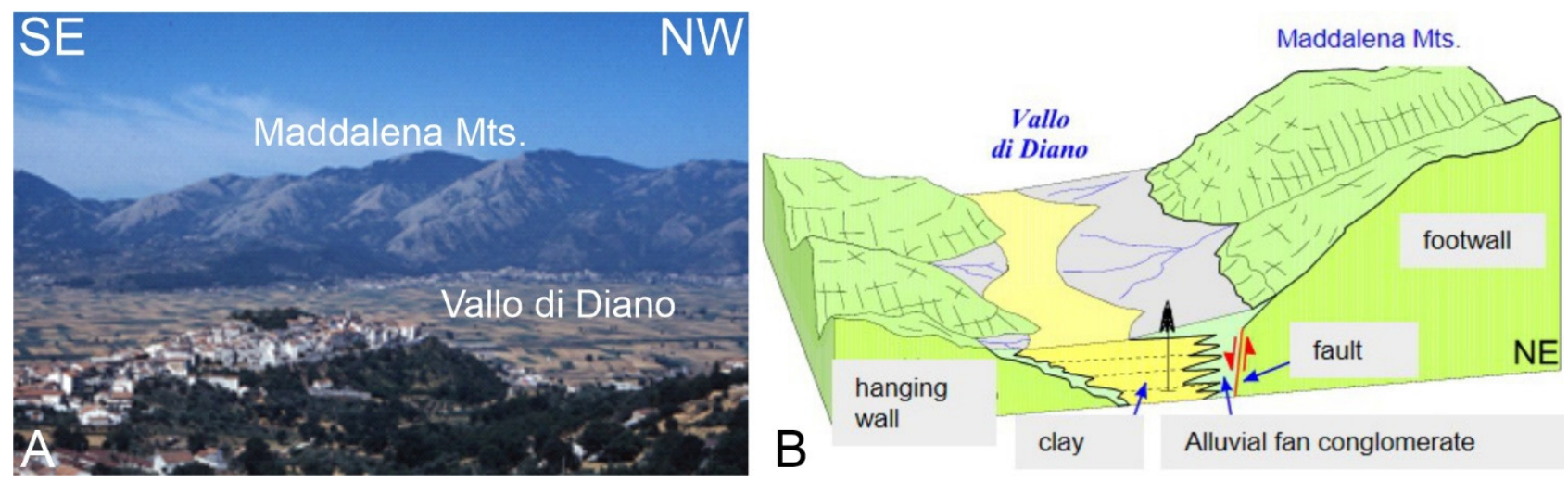

Figure 11. (A) Panoramic view of the Vallo di Diano basin from the town of Teggiano; (B) schematical geological model of the Vallo di Diano basin (modified from [47]).

The Vallo di Diano is also characterized by the presence of a wide system of coalescing alluvial fans, occurring along the footslope of the Maddalena Mts. These fans are still active and may cause serious alluvial problems. The most important and well-documented catastrophic floods that affected the Vallo di Diano basin date back to 1857. Such floods severely damaged the San Lorenzo Carthusia monastery, in the Padula area [65], one of the most important in Southern Italy.

In the last centuries, the town of Sala Consilina has also been repeatedly affected by severe flooding (in 1871; 1989; 1954; 2004), some of which were characterized by debris flows [66]. If events of the same magnitude as those occurred in the 19th century were to occur nowadays, the extent of the damage would be much larger than in the past, because the uncontrolled growth of urban areas has increased the real risk conditions.

\subsubsection{The Coastal Geoitinerary}

\section{Punta Telegrafo. Main Didactic Topics (Rock Deformation; Marine Terrace)}

The Punta Telegrafo cape (Figure 12A-C) is made up of highly deformed basinal deposits (Saraceno formation; Figure 12C), which show different plicative systems and structures. It has been considered by the structural geologists as a "sanctuary" for its didactic value. Moreover, a little cove nearby the cape preserves a very singular morphostratigraphical record that testifies for sea level oscillations due to past climate changes. Here, it is possible to observe a wave-cut terrace carved on the Saraceno Formation during the Last Interglacial period (Figure 12A) when the climate was warmer, and the sea level was higher than the present. Above it, continental slope breccias are well preserved (Figure 12B), which testify to the colder climate conditions that occurred during the Last Glacial period [39,67].

\section{Rizzico Landslide. Main Didactic Topics: Large Landslide and Related Impact on Roads and Railways}

The Rizzico landslide affects the left flank of a small catchment, named the Fiumicello River basin, close to its mouth. The landslide affects a deformed turbidite sequence consisting of alternating calcarenites, marls and clayey layers [60], which belongs to the Saraceno Formation [39]. The landslide is a slow moving, active, deep-seated rockslide [68,69] that affects a main road and a railway. Moreover, the railway connects Calabria and Sicily with the rest of Italy, so possible damages because of the landslide activity may cause several 
problems to these regions. Due to its relevance, the Rizzico landslide has been proposed as a moving geosite [60].
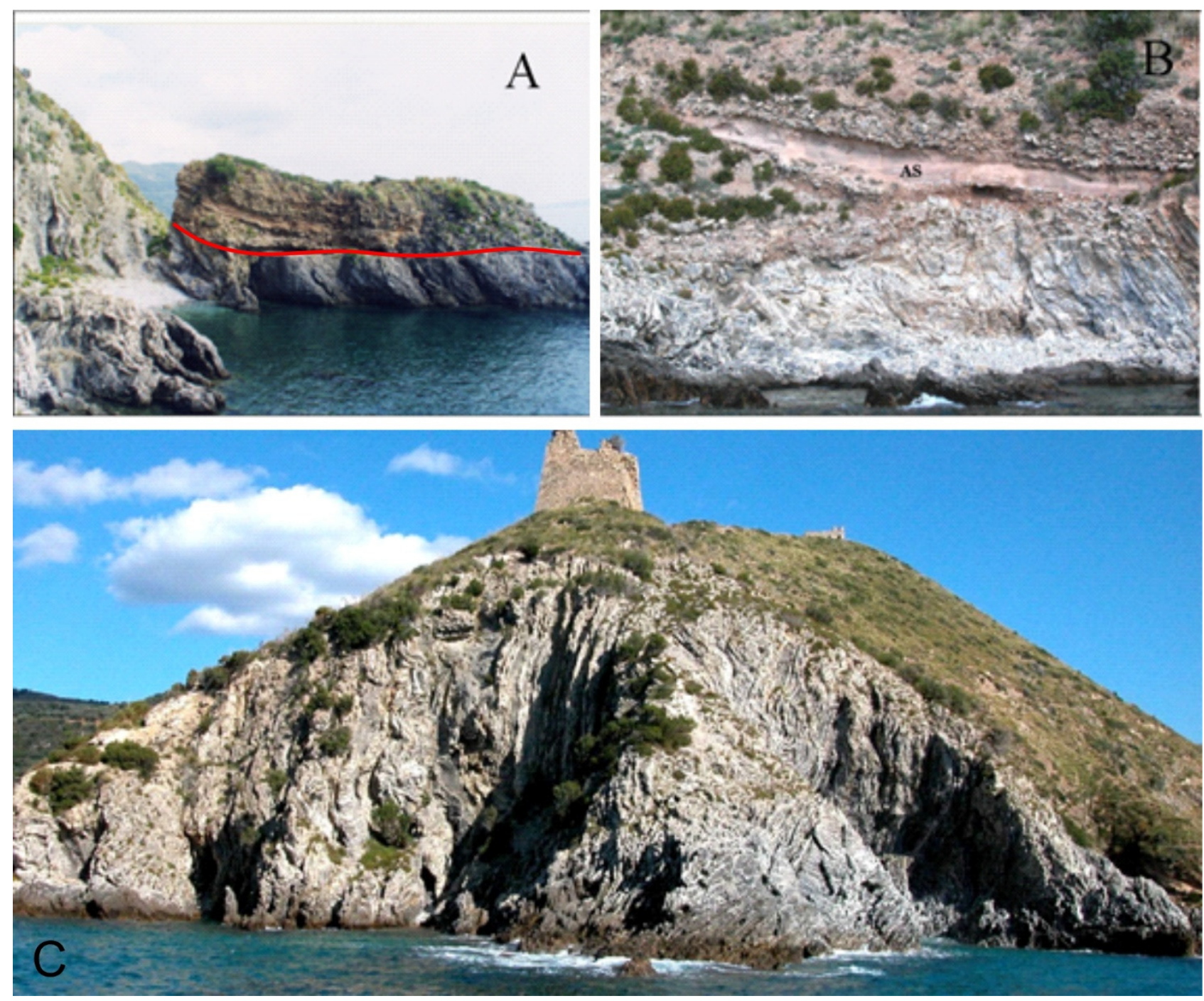

Figure 12. (A) Marine terrace along Punta Telegrafo (indicated by the red line) mantled by Upper Pleistocene breccias; (B) detail of the breccia deposits. The label AS refers to a pyroclastic level that has been correlated with the Campania Ignimbrite (39 ka) tephra by Marciano et al. [67]; (C) deformed bedrock units.

Fossil Dunes and Tyrrhenian Deposits of Palinuro. Main Didactic Topics: Quaternary Deposits: Last Interglacial

At the back of the Saline beach, it is possible to observe a well-preserved succession of aeolian deposits belonging to the end of Upper Pleistocene. They are easily recognizable from the road because of the badland-like erosion processes.

In the Lido Ficocelle locality, near the Palinuro harbour, the Last Interglacial coastal succession is well exposed. This is made by conglomerates and sands with several sedimentary structures (submerged and emerged beach deposits). Both successions can be easily described for didactic purposes.

Lambro and Mingardo Rivers. Main Didactic Topics: Entrenched Meanders, Natural Arc

This locality of the Geopark is characterized by the presence of two river mouths (namely the Lambro and Mingardo river mouths) that are located closely to each other. The Lambro River mouth is a nice example of a gorge with an entrenched meandering 
pattern (Figure 13A). From the Mingardo river mouth it is possible to access to the little bay where a wide natural coastal arch, named the "Palinuro arch", is preserved, which is an iconic image of the Geopark (Figure 13B). In this place, it is possible to discuss the coastal process that led to arch formation and, also, to face the problem of cliff instability due to rockfall and the following risk conditions in the associated beach/bay. The arch instead is in precarious stability conditions and several mitigation works have been carried out by the local authorities to allow access to the beach in safety.
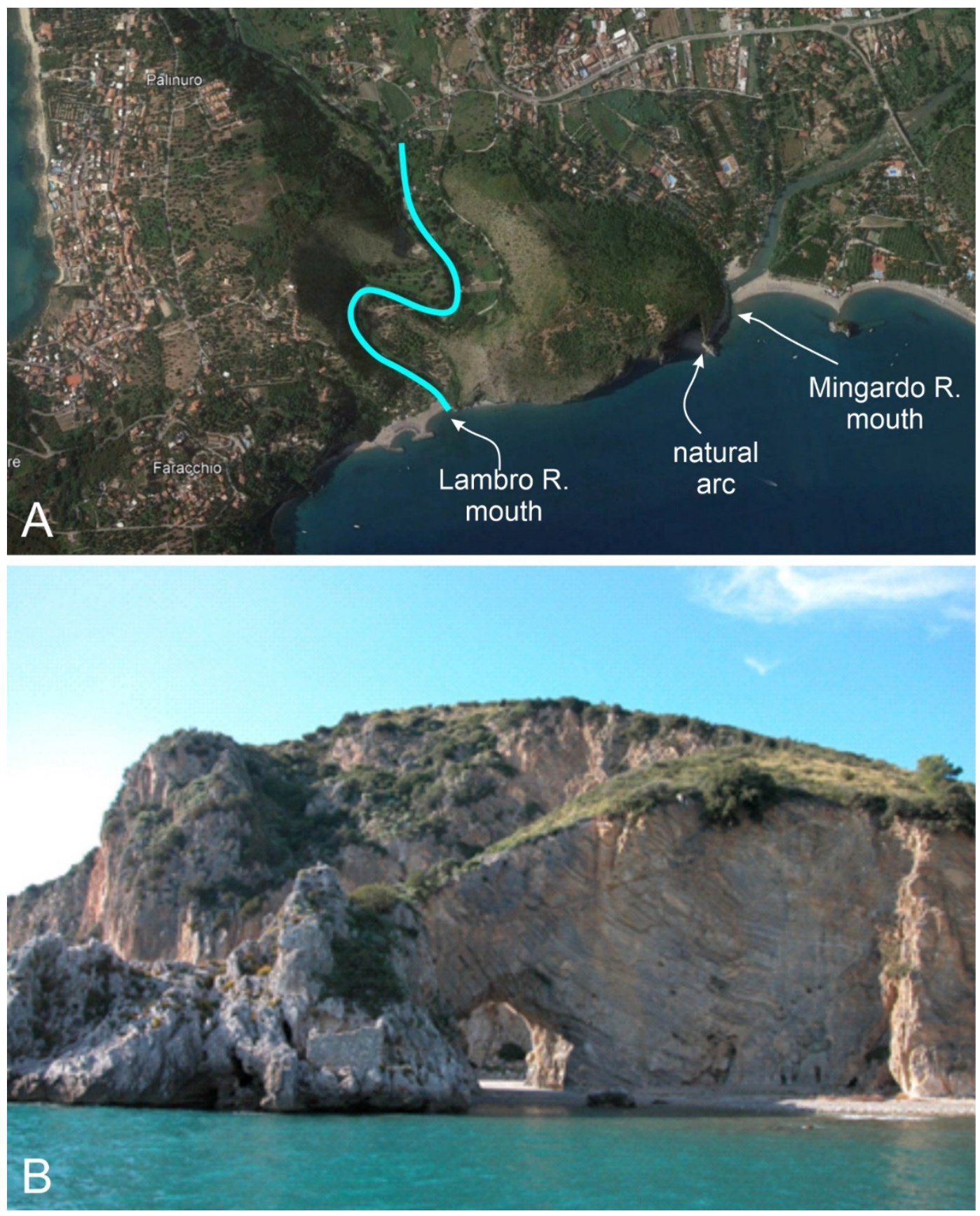

Figure 13. (A) Google Earth images showing the location of the Lambro and Mingardo rivers mouths and the Natural Arch of Palinuro. Cyan line indicates the gorge with an entrenched meandering pattern; (B) photo of the Natural Arch of Palinuro. 
At the Mingardo river mouth, it is also possible to rent a boat and have a tour of the Palinuro cape. During the tour it will be possible to observe the high cliffs carved on the Mesozoic limestone successions, together with several karst coastal caves, abrasion platform and notches sculpted by the sea during the Last Interglacial period, when the sea level was higher than the present (around $+6 \mathrm{slm}$ ). Some of the more famous landforms of this portion of the coast are the Fenestrella Arch (Figure 14A) and the Cave of Cala Fetente (Figure 14B).
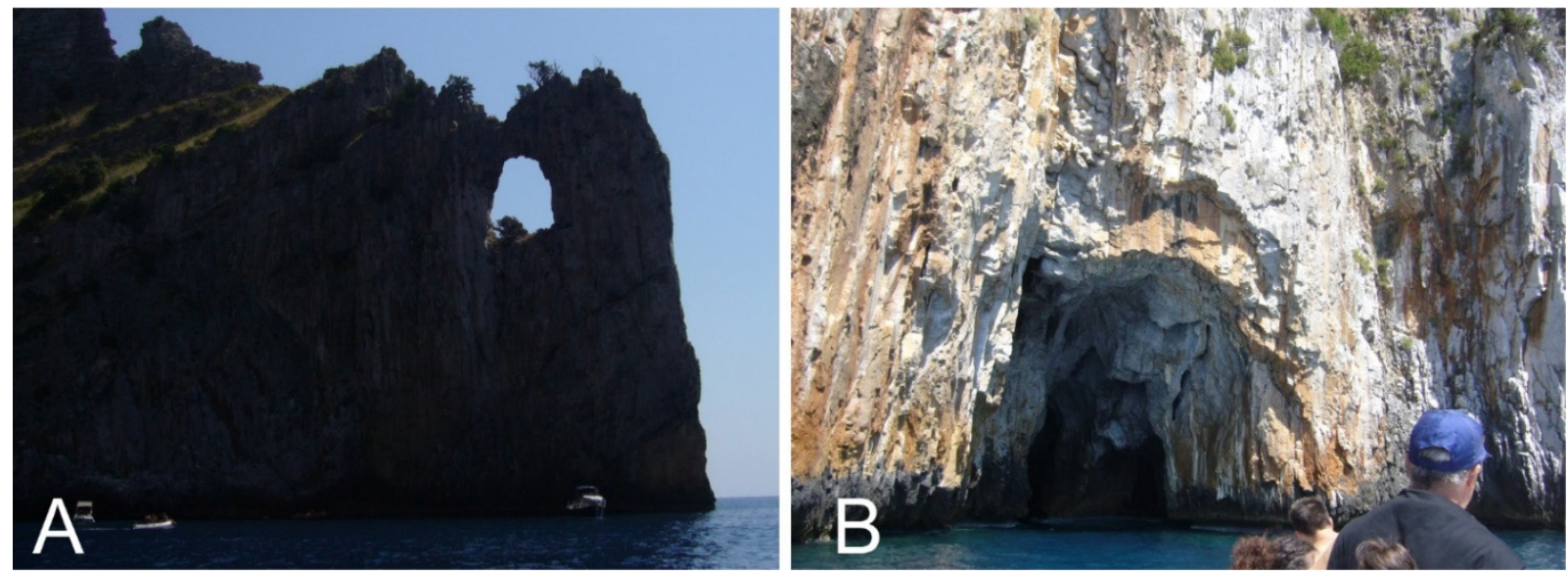

Figure 14. (A) The Fenestrella Arch; (B) the cave of Cala Fetente, which already attracts many tourists.

\section{Discussion and Conclusions}

The main goal of our work is to provide an example of how geosites and geomorphosites can be used to disseminate geological knowledge through geotourism. This approach could be useful to the development of a geotourism strategy in the CVDA Geopark with positive feedbacks for the growth of the local economy. According to Dowling and Newsome [8], geotourism is "geologically based, promotes geoconservation, fosters geo-education through geo-interpretation, and contribute to an area or region's sustainable development through economic and social benefits". The large interest of the scientific community in geotourism is expressed by the number of papers published in peer-reviewed journals that increased abruptly from the first to the second decade of the 21st century [6]. This clearly reflects the importance of geoparks as attractors for geotourists, also considering that most of these papers refer to central and western Europe, and China, which are also the areas where UNESCO Global Geoparks are more widespread. One of the main geological and geomorphological attractors are karst areas, which are spread throughout $37 \%$ of geoparks worldwide [32], and that may significantly contribute to the increase in the local economy [70,71]. In the CVDA Geopark, the importance of karst areas as a geotourism attractor is testified by the large number of geosites (46 out of 160 , which corresponds to $29 \%$ of the total) that exhibits karst features. Moreover, 8 geosites and geomorphosites among the 20 sites we selected for the proposed geoitineraries are karst landforms (Table 1).

It is worthy to note that a quantitative assessment of the educational and touristic potential of a certain area is a crucial point to select sites to include in a geoitinerary. Regarding our study area, this approach has been locally adopted for specific sectors, such as the coastal area between Licosa Cape and Ascea [20], but a comprehensive analysis of all the geosites and geomorphosites of the Geopark has never been assessed. Our research aims at fixing this gap, and it is the first attempt carried out at the entire Geopark scale.

To test the potential of both the inner and coastal geoitineraries to be included in a geotourism program, we analysed their strengths, weakness, opportunities, and threats (SWOT). Results of such analysis are reported in Table 2. 
Table 2. Results of the SWOT (strengths, weaknesses, opportunities, and threats) analysis for the inner geoitinerary.

\begin{tabular}{|c|c|}
\hline Strengths & Weaknesses \\
\hline $\begin{array}{l}\text { 1. Discovery of a poorly known portion of the Cilento, Vallo di Diano } \\
\text { and Alburni UNESCO Global Geopark (e.g., its inner sector). } \\
\text { 2. Some sites already attract many tourists (e.g., the archaeological } \\
\text { area of Paestum and the coast of Palinuro). } \\
\text { 3. High didactic value to explain geological and geomorphological } \\
\text { processes acting at different time scales. } \\
\text { 4. Sites are easily accessible by car. } \\
\text { 5. Sites are also accessible to people not used to outdoor (e.g., } \\
\text { trekking) activities. } \\
\text { 6. Opportunity to rest and to have a swim in amazing beaches. } \\
\text { 7. Sites around Palinuro Cape are accessible by boat thus allowing the } \\
\text { enjoyment of a boat trip. }\end{array}$ & $\begin{array}{l}\text { 1. The geoitinerary is at an initial stage and } \\
\text { deserves the development of further activities, } \\
\text { such as explanatory panels for each stop. } \\
\text { The geoitinerary is a personal initiative by the } \\
\text { Authors and lacks, up to now, an intense } \\
\text { collaboration with local administration. } \\
\text { The full development of the geoitinerary needs } \\
\text { funding and a management policy. } \\
\text { Local people and local administration have not } \\
\text { yet fully understood the high touristic and } \\
\text { didactic potential of the area. } \\
\text { Tourist traffic is limited to few sites, which are } \\
\text { the archaeological area of Paestum and the karst } \\
\text { canyon of Magliano Vetere. } \\
\text { Local accommodation facilities can host very } \\
\text { little tourist traffic. } \\
\text { Public transport does not allow easy moving } \\
\text { between stops. } \\
\text { The geoitinerary could be hard to be followed in } \\
\text { the winter period because of intense rainfall and } \\
\text { the accumulation of snow. } \\
\text { The Natural Arc at the Mingardo River mouth is } \\
\text { 9ometimes not accessible because of rock falls. }\end{array}$ \\
\hline
\end{tabular}

1. The geoitinerary could be integrated into a wider tour because of its closeness with the main touristic attraction of the Geopark.

2. The geoitinerary could lead many tourists to move from the touristic coastal areas of Cilento to the poorly known inner areas of the Geopark.

3. This tourist flow could help the growth of the local economy (e.g., by increasing the number of accommodation facilities).

4. The growth of the local economy could provide work for young people and so it could reduce the abandonment of small mountain villages.

5. The geoitineraries are two days long thus providing enough time for the tourists to enjoy the hospitality of local people and food of excellent quality.

1. Lack of financial resources to develop the geoitinerary.

2. Low interest in local authorities for the development of geotourism.

This is another step that, combined with already published geoitineraries, may contribute to the discovery of some poorly known portions of the CVDA Geopark (e.g., the inner hilly to mountainous areas). Attracting geotourists in areas not affected by significant tourist traffic plays a crucial role in helping the growth of the local economy, which could also be reflected in the reduction of the abandonment of small villages by young people. Regarding tourist traffic within the CVDA Geopark, the number of tourists that visit it is not continuously monitored by local administrations, which makes the reconstruction of the traffic flux and its yearly trends a challenging task [72]. Some data may be derived by the Italian Institute of Statistics (www.istat.it, accessed on 28 September 2021) and the Ente Provinciale del Turismo of Salerno that suggests that a number between 2 and 4 million tourists visit the Geopark yearly [72]. This tourist traffic is mainly concentrated along the coastal sector of the Geopark and in summer, with about $95 \%$ of the tourists visiting these areas in 2017 [73,74].

The development of geotourism should also be addressed to disseminate geological and geomorphological knowledge to non-experts. The dissemination strategy aims to make 
people aware of the dynamic environment they live in and to face topics such as landscape evolution and related risks for human lives and infrastructures. For this purpose, the correct selection of sites with high educational potential is a fundamental task that could determine the effective success of a geotourism program. We unfortunately must notice that the development of this topic is already at an early stage, as it can be realized by visiting the Geopark website. We think that, since the CVDA Geopark was founded about 10 years ago, Geopark administrators focused their attention on other topics (e.g., Mediterranean diet and biodiversity) with respect to the development of a well-planned geotourism program. Furthermore, understanding the reasons for the poor interest of local economic actors towards geotourism is far beyond the goals of our study. This point is also beyond our expertise and should be faced by other experts, such as economists and tourist managers. We are doing our best in this paper and already published papers [18-20] to fix this gap and to enhance the high didactic potential of most of the geosites and geomorphosites of the CVDA Geopark.

Supplementary Materials: The following are available online at https://www.mdpi.com/article/10.339 0/geosciences11110466/s1, Table S1, Potential Educational Value; Table S2, Potential Touristic Value.

Author Contributions: Conceptualization, E.V. and N.S.; methodology, E.V., A.C., M.F., L.P. and A.S.; software, E.V., A.C., M.F., L.P. and A.S.; validation, E.V. and N.S.; formal analysis, A.C., M.F., L.P. and A.S.; investigation, E.V., A.C., M.F., L.P., A.S. and N.S.; data curation, E.V. and N.S.; writing-original draft preparation, E.V. and N.S.; writing-review and editing, E.V and N.S..; visualization, A.C., M.F., L.P., A.S.; supervision, E.V. and N.S. All authors have read and agreed to the published version of the manuscript.

Funding: This research received no external funding.

Conflicts of Interest: The authors declare no conflict of interest.

\section{References}

1. Dowling, R.; Newsome, D. The scope and nature of geotourism. In Geotourism; Dowling, R., Newsome, D., Eds.; Routledge: Oxford, UK, 2006; pp. 31-53.

2. Newsome, D.; Dowling, R.K. Setting an agenda for geotourism. In Geotourism: The tourism of Geology and Landscape; Goodfellow Publishers: Oxford, UK, 2010; pp. 1-12.

3. Newsome, D.; Dowling, R. Geoheritage and Geotourism; Elsevier BV: Amsterdam, The Netherlands, 2018 ; pp. 305-321.

4. Hose, T.A. Selling the Story of Britain's Stone. Environ. Interpret. 1995, 10, 16-17.

5. Hose, T.A. 3G's for Modern Geotourism. Geoheritage 2012, 4, 7-24. [CrossRef]

6. Ólafsdóttir, R.; Tverijonaite, E. Geotourism: A Systematic Literature Review. Geosciences 2018, 8, 234. [CrossRef]

7. Piacentini, T.; Castaldini, D.; Coratza, P.; Farabollini, P.; Miccadei, E. Geotourism: Some examples in northern-central Italy. GeoJ. Tour. Geosites 2011, 8, 240-262.

8. Dowling, R.; Newsome, D. Chapter 1: Geotourism: Definition, characteristics and international perspectives. In Handbook of Geotourism; Edward Elgar Publishing: Cheltenham, UK; Camberley, UK, 2018; pp. 1-22.

9. The Arouca Declaration. Available online: http://www.unesco.org/new/fileadmin/MULTIMEDIA/HQ/SC/pdf/Geopark_ Arouca_Declaration_EGN_2012.pdf (accessed on 14 September 2021).

10. Reynard, E. Protecting Stones: Conservation of erratic blocks in Switzerland. In Dimension Stone 2004, New Perspectives for a Traditional Building Material; Prykril, R., Ed.; A.A. Balkema Publishers: Leiden, The Netherlands, 2004; pp. 3-7.

11. Panizza, M. Geomorphosites: Concepts, methods and examples of geomorphological survey. Chin. Sci. Bull. 2001, 46, 4-5. [CrossRef]

12. Zouros, N. The European Geoparks Network-Geological heritage protection and local development. Episodes 2004, $27,165-171$. [CrossRef]

13. Eder, F.W. Geoparks-GEOLOGICAL attractions: A tool for public education, recreation and sustainable economic development. Episodes 2004, 27, 162-164. [CrossRef]

14. UNESCO Global Geopark Definition. Available online: http://www.globalgeopark.org/aboutGGN/6398.htm (accessed on 14 September 2021).

15. Map of UNESCO Global Geopark. Available online: http://www.globalgeopark.org/aboutGGN/MemberList/index.htm (accessed on 14 September 2021).

16. Santangelo, N.; Santo, A.; Guida, D.; Lanzara, R.; Siervo, V. The geosites of the Cilento-Vallo di Diano national park (Campania region, southern Italy). Il Quat. 2005, 18, 101-112. 
17. Cilento, Vallo di Diano and Alburni Geopark Geosites Database. Available online: http://www.cilentoediano.it/it/geositi-gliambiti-paesaggio (accessed on 15 September 2021).

18. Valente, E.; Santo, A.; Guida, D.; Santangelo, N. Geotourism in the Cilento, Vallo di Diano and Alburni UNESCO Global Geopark (Southern Italy): The Middle Bussento Karst System. Resources 2020, 9, 52. [CrossRef]

19. Santangelo, N.; Romano, P.; De Santo, A.V. Geo-itineraries in the Cilento Vallo di Diano Geopark: A Tool for Tourism Development in Southern Italy. Geoheritage 2014, 7, 319-335. [CrossRef]

20. Santangelo, N.; Amato, V.; Ascione, A.; Ermolli, E.R.; Valente, E. GEOTOURISM as a Tool for Learning: A Geoitinerary in the Cilento, Vallo di Diano and Alburni Geopark (Southern Italy). Resources 2020, 9, 67. [CrossRef]

21. Aloia, A.; De Vita, A.; Guida, D.; Toni, A.; Valente, A. National Park of Cilento and Vallo di Diano: Geodiversity, geotourism, geoarchaeology and historical tradition. In Proceedings of the 9th European Geopark Conference-European Geopark Network, Mytilene Lesvos, Greece, 1-5 October 2010; p. 41.

22. Aloia, A.; De Vita, A.; Guida, D.; Toni, A.; Valente, A. La geosiversità del Parco Nazionale del Cilento e Vallo di Diano: Verso il Geoparco. In Proceedings of the Atti del Convegno Nazionale "Il Patrimonio Geologico: Una risorsa da proteggere e valorizzare", Sasso di Castalda, Italy, 29-30 April 2010; pp. 188-202.

23. Aloia, A.; Guida, D.; Valente, A. Geodiversity in the Geopark of Cilento and Vallo di Diano as heritage and resource development. Rend. Online Soc. Geol. Ital. 2012, 21, 688-690.

24. Aloia, A.; Guida, D. The Geosites: Geopark's Gaia Synphony in the Cilento, Vallo Diano and Alburni Geopark, Geopark Book n. 1; Cilento, Vallo di Diano and Alburni Geopark: Vallo della Lucania, Italy, 2014.

25. Calcaterra, D.; D’Argenio, B.; Ferranti, L.; Pappone, G.; Petrosino, P. Guide Geologiche Regionali, Campania e Molise; Società Geologica Italiana: Rome, Italy, 2016; p. 276.

26. Mazzoli, S.; Helman, M. Neogene patterns of relative plate motion for Africa-Europe: Some implications for recent central Mediterranean tectonics. Geol. Rundsch. 1994, 83, 464-468. [CrossRef]

27. Turco, E.; Macchiavelli, C.; Mazzoli, S.; Schettino, A.; Pierantoni, P. Kinematic evolution of Alpine Corsica in the framework of Mediterranean mountain belts. Tectonophysics 2012, 579, 193-206. [CrossRef]

28. Ciarcia, S.; Mazzoli, S.; Vitale, S.; Zattin, M. On the tectonic evolution of the Ligurian accretionary complex in southern Italy. Bulletin 2011, 124, 463-483. [CrossRef]

29. Ascione, A.; Ciarcia, S.; DI Donato, V.; Mazzoli, S.; Vitale, S. The Pliocene-Quaternary wedge-top basins of southern Italy: An expression of propagating lateral slab tear beneath the Apennines. Basin Res. 2011, 24, 456-474. [CrossRef]

30. Mazzoli, S.; Szaniawski, R.; Mittiga, F.; Ascione, A.; Capalbo, A. Tectonic evolution of Pliocene-Pleistocene wedge-top basins of the southern Apennines: New constraints from magnetic fabric analysis. Can. J. Earth Sci. 2012, 49, 492-509. [CrossRef]

31. Gray, J.M. Geodiversity: Developing the paradigma. Proc. Geol. Assoc. 2008, 119, 287-298. [CrossRef]

32. Ruban, D. Quantification of geodiversity and its loss. Proc. Geol. Assoc. 2010, 121, 326-333. [CrossRef]

33. Santangelo, A.; Santo, A. Endokarst processes in the Alburni massif (Campania, Southern Italy): Evolution of ponors and hydrogeological implications. Z. Geomorphol. 1997, 41, 229-246. [CrossRef]

34. Vitale, S.; Ciarcia, S. Tectono-stratigraphic and kinematic evolution of the southern Apennines/Calabria-Peloritani Terrane system (Italy). Tectonophysics 2013, 583, 164-182. [CrossRef]

35. Corrado, S.; Aldega, L.; Perri, F.; Critelli, S.; Muto, F.; Schito, A.; Tripodi, V. Detecting syn-orogenic extension and sediment provenance of the Cilento wedge top basin (southern Apennines, Italy): Mineralogy and geochemistry of fine-grained sediments and petrography of dispersed organic matter. Tectonophysics 2019, 750, 404-418. [CrossRef]

36. Geological Map of Italy at Scale 1:50,000, Sheet 502-Agropoli. Available online: http:/ /www.isprambiente.gov.it/Media/carg/ 502_AGROPOLI/Foglio.html (accessed on 30 September 2021).

37. Geological Map of Italy at Scale 1:50,000, Sheet 503-Vallo. Available online: http://www.isprambiente.gov.it/Media/carg/503_ VALLO/Foglio.html (accessed on 30 September 2021).

38. Geological Map of Italy at Scale 1:50,000, Sheet 519-Capo Palinuro. Available online: http://www.isprambiente.gov.it/Media/ carg/519_CAPO_PALINURO/Foglio.html (accessed on 30 September 2021).

39. Vitale, S.; Ciarcia, S.; Mazzoli, S.; Zaghloul, M. Tectonic evolution of the 'Liguride' accretionary wedge in the Cilento area, southern Italy: A record of early Apennine geodynamics. J. Geodyn. 2011, 51, 25-36. [CrossRef]

40. Vitale, S.; Ciarcia, S.; Fedele, L.; Tramparulo, F.D. The Ligurian oceanic successions in southern Italy: The key to decrypting the first orogenic stages of the southern Apennines-Calabria chain system. Tectonophysics 2019, 750, 243-261. [CrossRef]

41. Ascione, A.; Romano, P. Vertical movements on the eastern margin of the Tyrrhenian extensional basin. New data from Mt. Bulgheria (Southern Apennines, Italy). Tectonophysics 1999, 315, 337-356. [CrossRef]

42. Iannace, A.; Romano, P.; Santangelo, N.; Santo, A.; Tuccimei, P. The OIS 5c along Licosa cape promontory (Campania region, southern Italy): Morphostratigraphy and U/Th dating. Z. Geomorphol. 2001, 45, 307-319. [CrossRef]

43. Cinque, A.; Romano, P.; Rosskopf, C.; Santangelo, N.; Santo, A. Morfologie costiere e depositi quaternari tra Agropoli e Ogliastro Marina (Cilento-Italia Meridionale). Il Quat. 1994, 7, 3-16.

44. Cinque, A.; Rosskopf, C.; Barra, D.; Campajola, L.; Paolillo, G.; Romano, P. Nuovi dati stratigrafici e cronologici sull'evoluzione recente della piana del fiume Alento (Cilento, Campania). Il Quat. 1995, 8, 323-338. 
45. Karner, D.; Juvigne, E.; Brancaccio, L.; Cinque, A.; Ermolli, E.R.; Santangelo, N.; Bernasconi, S.; Lirer, L. A potential early middle Pleistocene tephrostratotype for the Mediterranean basin: The Vallo Di Diano, Campania, Italy. Glob. Planet. Chang. 1999, 21, 1-15. [CrossRef]

46. Santangelo, N.; Amato, M.; Ascione, A.; Cafaro, S.; Calcatera, D.; Romano, P. Geological field trip n. 4: From Vallo di Diano to Angelo caves. In Field Trip Guide Book $12^{\circ}$ European Geopark Conference; Aloia, A., Calcaterra, D., Guida, D., Valloni, R., Eds.; National Park of Cilento Vallo di Diano and Alburni: Vallo della Lucania, Italy, 2013; pp. 42-52.

47. Santangelo, N.; Bravi, S.; Santo, A. Itinerario 12 Piana del Sele, Monti Alburni e Vallo di Diano. In Guide Geologiche RegionaliCampania e Molise; Calcaterra, D., D’Argenio, B., Ferranti, L., Pappone, G., Petrosino, P., Eds.; Società Geologica Italiana: Rome, Italy, 2016; pp. 227-242. ISBN 9788894022728.

48. Vitale, S.; Amore, O.; Ciarcia, S.; Lo Schiavo, L.; Santangelo, N.; Tramparulo, F. Itinerario 11-Cilento settentrionale. In Guide Geologiche Regionali_Campania e Molise; Calcaterra, D., D'Argenio, B., Ferranti, L., Pappone, G., Petrosino, P., Eds.; Società Geologica Italiana: Rome, Italy, 2016; pp. 69-80. ISBN 9788894022728.

49. Brilha, J.B. Inventory and Quantitative Assessment of Geosites and Geodiversity Sites: A Review. Geoheritage 2016, 8, 119-134. [CrossRef]

50. Dyson, R. Strategic development and SWOT analysis at the University of Warwick. Eur. J. Oper. Res. 2004, 152, 631-640. [CrossRef]

51. Carrión-Mero, P.; Loor-Oporto, O.; Andrade-Ríos, H.; Herrera-Franco, G.; Morante-Carballo, F.; Jaya-Montalvo, M.; AguilarAguilar, M.; Torres-Peña, K.; Berrezueta, E. Quantitative and Qualitative Assessment of the "El Sexmo" Tourist Gold Mine (Zaruma, Ecuador) as A Geosite and Mining Site. Resources 2020, 9, 28. [CrossRef]

52. Kubalíková, L.; Kirchner, K. Geosite and Geomorphosite Assessment as a Tool for Geoconservation and Geotourism Purposes: A Case Study from Vizovická vrchovina Highland (Eastern Part of the Czech Republic). Geoheritage 2016, 8, 5-14. [CrossRef]

53. NASA Shuttle Radar Topography Mission. Available online: https://srtm.csi.cgiar.org/srtmdata/ (accessed on 20 September 2021).

54. Amato, V.; Aucelli, P.P.C.; D'Argenio, B.; Da Prato, S.; Ferraro, L.; Pappone, G.; Petrosino, P.; Rosskopf, C.M.; Ermolli, E.R. Holocene environmental evolution of the costal sector in front of the Poseidonia-Paestum archaeological area (Sele plain, southern Italy). Rend. Lince 2012, 23, 45-59. [CrossRef]

55. Illustrative Notes of the Geological Map of Italy at Scale 1:50,000, Sheet 486-Foce del Sele. Available online: https://www. isprambiente.gov.it/Media/carg/note_illustrative/486_FocedelSele.pdf (accessed on 26 October 2021).

56. Migoń, P.; Pijet-Migoń, E. Viewpoint geosites—Values, conservation and management issues. Proc. Geol. Assoc. 2017, 128, 511-522. [CrossRef]

57. Valiante, M.; Guida, D.; Della Seta, M.; Bozzano, F. A spatiotemporal object-oriented data model for landslides (LOOM). Landslides 2021, 18, 1231-1244. [CrossRef]

58. De Riso, R.; Santo, A. Geologia, evoluzione geomorfologica e frane del bacino del T. Pietra (Campania). Quad. Geol. Appl. 1997, 4, 19-33.

59. Technical Map of the Campania Region at Scale 1:5000. Available online: https://sit2.regione.campania.it/content/carta-tecnicaregionale-2004-2005 (accessed on 30 October 2021).

60. Calcaterra, D.; Guida, D.; Budetta, P.; De Vita, P.; Di Martire, D.; Aloia, A. Moving geosites: How landslides can become focal points in Geoparks. Latest Trends Eng. Mech. Struct. Eng. Geol. 2014, 2, 162-171.

61. Piperno, M. La Preistoria alle Falde del M. Cervati; Parco Nazionale del Cilento e Vallo di Diano, Ed.; Cilento, Vallo di Diano and Alburni Geopark: Vallo della Lucania, Italy, 2001; p. 12.

62. Villani, F.; Pierdominici, S. Late Quaternary tectonics of the Vallo di Diano basin (southern Apennines, Italy). Quat. Sci. Rev. 2010, 29,3167-3183. [CrossRef]

63. Santangelo, N. Evoluzione Stratigrafica, Geomorfologica Eneotettonica di Alcuni Bacini Lacustri del Confine Campano Lucano (Italia Meridionale). Ph.D. Thesis, University of Naples "Federico II", Naples, Italy, 1991. Unpublished.

64. Ascione, A.; Cinque, A.; Santangelo, N.; Tozzi, M. Il bacino del Vallo di Diano e la tettonica trascorrente plio-quaternaria: Nuovi vincoli cronologici e cinematici. Studi Geol. Camerti 1992, 1, 201-208.

65. Budetta, P.; Santangelo, N.; Santo, A. Interazioni tra processi alluvionali e insediamenti abitativi in epoca storica: Il caso della Certosa di Padula. I Convegno GeoBen 2000, 6, 41-48.

66. Santangelo, N.; Daunisiestadella, J.; Di Crescenzo, G.; DI Donato, V.; Faillace, P.I.; Martín-Fernández, J.A.; Romano, P.; De Santo, A.V.; Scorpio, V. Topographic predictors of susceptibility to alluvial fan flooding, Southern Apennines. Earth Surf. Process. Landf. 2012, 37, 803-817. [CrossRef]

67. Marciano, R.; Munno, R.; Petrosino, P.; Santangelo, N.; Santo, A.; Villa, I. Late quaternary tephra layers along the Cilento coastline (southern Italy). J. Volcanol. Geotherm. Res. 2008, 177, 227-243. [CrossRef]

68. De Vita, P.; Cusano, D.; La Barbera, G. Complex Rainfall-Driven Kinematics of the Slow-Moving Pisciotta Rock-Slide (Cilento, Southern Italy). In Advancing Culture of Living with Landslides; Mikos, M., Casagli, N., Yin, Y., Sassa, K., Eds.; Springer: Cham, Switzerland, 2017; Volume 4, pp. 547-556.

69. De Vita, P.; Carratù, M.; La Barbera, G.; Santoro, S. Kinematics and geological constraints of the slow-moving Pisciotta rock slide (southern Italy). Geomorphology 2013, 201, 415-429. [CrossRef]

70. Calaforra, J.M.; Fernandez-Cortes, A. Geotourism in Spain: Resources, environmental management. In Geotourism. Sustainabilty, Impact and Management; Dowling, R., Newsome, D., Eds.; Elsevier: Oxford, UK, 2006; pp. 199-220. 
71. Doorne, S. Caves, Cultures and Crowds: Carrying Capacity Meets Consumer Sovereignty. J. Sustain. Tour. 2000, 8, 116-130. [CrossRef]

72. Amodio, T. La dimensione territoriale dell'ospitalità turistica in provincia di Salerno. Boll. Dell'associazione Ital. Cartogr. 2016, 157, 105-116. [CrossRef]

73. Italan Ministry of the Environment, Technical Analysis 2017. Available online: https://www.minambiente.it/sites/default/files/ archivio/allegati/biodiversita/Rapporto_Natura_Cultura.pdf (accessed on 31 May 2020).

74. Di Martino, P.; Petrillo, C.S. An International Project to Develop Networking for Promoting a Specific Destination: Emigration as a Tool to Enhance Tourism in Cilento Area. In Tourism Local Systems and Networking; Elsevier BV: Amsterdam, The Netherlands, 2006; pp. 219-233. 